https://helda.helsinki.fi

\title{
China, the Dollar Peg and U.S. Monetary Policy
}

\section{Tervala, Juha}

2014

Tervala , J 2014 , ' China, the Dollar Peg and U.S. Monetary Policy ' , HECER discussion papers, no. 377 . <

https://helda.helsinki.fi/bitstream/handle/10138/42675/HECER_DP377.pdf >

http://hdl.handle.net/10138/136206

acceptedVersion

Downloaded from Helda, University of Helsinki institutional repository.

This is an electronic reprint of the original article.

This reprint may differ from the original in pagination and typographic detail.

Please cite the original version. 


\title{
China, the Dollar Peg and U.S. Monetary Policy
}

\author{
Juha Tervala \\ University of Helsinki and HECER
}

Discussion Paper No. 377

January 2014

ISSN 1795-0562

HECER - Helsinki Center of Economic Research, P.O. Box 17 (Arkadiankatu 7), FI-00014 University of Helsinki, FINLAND, Tel +358-9-191-28780, Fax +358-9-191-28781,

E-mail info-hecer@helsinki.fi, Internet www.hecer.fi 


\title{
China, the Dollar Peg and U.S. Monetary Policy
}

\begin{abstract}
I examine the transmission of expansionary U.S. monetary policy in case where developing countries--including China--peg their currencies to the dollar. I evaluate the value of the dollar peg as a fraction of consumption that households would be willing to pay for the dollar peg to remain as well off under the dollar peg as under a flexible exchange rate. The value of the dollar peg is positive for the dollar bloc because the U.S. can no longer improve its terms of trade at the dollar bloc's expense. This provides a rationale for fixing the exchange rate. If the expenditure switching effect is weak, the peg is harmful to the U.S., providing a rationale for criticism of China's exchange rate policy.
\end{abstract}

JEL Classification: E32, E52, F30, F41, F44

Keywords: Dollar peg, dollar bloc, monetary policy, open economy macroeconomics

Juha Tervala

Department of Political and Economic Studies

University of Helsinki

P.O. Box 17 (Arkadiankatu 7)

FI-00014 University of Helsinki

FINLAND

e-mail: juha.tervala@helsinki.fi 


\section{Introduction}

The international transmission of U.S. monetary policy and China's exchange rate policy during the recent global recession have been topics of heated debate. The U.S. Federal Reserve (Fed) has been accused of competitive devaluation, which deliberately attempts to depreciate the dollar and stimulate the U.S. economy and-in particular-its exports at the expense of the rest of the world. Stiglitz (2008 \& 2010), for instance, argues that U.S. interest rate reductions are a beggar-thy-neighbor policy as they have depreciated the dollar and helped to export the weakness of the U.S. economy to other countries.

Rajan (2011) argues that expansionary U.S. monetary policy represents a threat not only to the rest of the world, but also to the U.S. itself. The argument goes as follows: U.S. interest rate reductions are followed by identical cuts everywhere, because no country wants its currency to appreciate strongly against the dollar. Consequently, the Fed ends up setting monetary policy for the rest of the world also. Expansionary U.S. monetary policy that is appropriate for the U.S. economy may be overly aggressive for emerging markets, where it leads to asset bubbles and inflation. If the rest of the world then becomes reluctant to fund U.S. spending, the adjustment will be painful for the U.S. also.

The Economist (2011) emphasized that 66 countries have either adopted the dollar as legal tender, pegged their currency to it or manage their exchange rate against it. The dollar bloc's collective GDP was almost 9 trillion dollars, or about $14 \%$ of the world economy. The dollar bloc comprises oil producers and developing countries. Erceg et al. (2011) mention that various motivations for the dollar peg have been offered, including the desire to keep currencies weak and exports competitive and to avoid the adverse effects of exchange rate fluctuations on the balance sheets of domestic firms and households. The dollar peg also serves as a strong and easily understood anchor for monetary policy (Abed et al. 2003).

The largest member of the dollar bloc-by far-is China. It has engaged in massive currency manipulation to keep the yuan weak and its exports competitive during the global recession, when the Fed has cut interest rates aggressively. Krugman (2010) argues that this is "the most distortionary exchange rate policy any major nation has ever followed", and the U.S. Treasury should label China as a currency manipulator. Importantly, political pressure to do so has been rising (The Economist 2010).

In this paper, I use a New Keynesian open-economy model to examine the consequences of developing countries'-including China's-dollar peg for the international transmission of U.S. monetary policy. I assume that the dollar 
bloc pegs the exchange rate to the dollar by following U.S. monetary policy. In addition, I assume that all export prices are set in U.S. dollars, which I refer to as dollar pricing. The assumption of dollar pricing is consistent with the empirical evidence of Goldberg and Tille (2008), who find that $99.8 \%$ of U.S. exports and $92.8 \%$ of U.S. imports are invoiced in dollars.

The implications of China's currency manipulation has been actively debated. This paper contributes to the debate, first, by analyzing the consequences of China's dollar peg for the effectiveness of U.S. monetary policy. More important, I evaluate the value of the dollar peg for the dollar bloc and the U.S. I measure the value of the dollar peg as a fraction of consumption that households would be willing to pay for the dollar peg to remain as well off under the dollar peg as under a flexible exchange rate.

The theme is related to a classic question of whether pegging the exchange rate is optimal. Since the publication of Obstfeld and Rogoff (2002), a stand of the recent literature has analyzed the optimal choice of the exchange rate regime in the face of non-monetary shocks based on rigorous welfare analysis. ${ }^{1}$ This literature addresses the question of whether fixing the exchange rate during domestic shocks is optimal. However, the literature has not addressed the question of whether it is optimal for foreign countries to fix their exchange rate during domestic monetary shocks.

I first analyze the international effects of a U.S. interest rate cut under flexible exchange rates. This exercise shows two new results. If the elasticity of substitution between domestic and foreign good (cross-country substitutability, for short) is sufficiently high and a second-order approximation of the utility function is used, the U.S. welfare effect is negative. This result contrasts with that of Schmidt (2006), who using a first-order approximation of the utility function, finds that monetary expansion under dollar pricing is a beggar-thy-neighbor policy. A second-order approximation also takes into account the variance of employment and is qualitatively important for welfare when the cross-country substitutability is high. In this case, the welfare losses from a high variance of employment, caused by a strong expenditure switching effect, dominate the benefits of monetary expansion.

It has been challenging for models to provide for the observation that the positive correlation of output between the U.S. and foreign countries is larger than the positive correlation of consumptions (Backus et al. 1992). Under producer (local) currency pricing, a monetary shock generates a negative (positive) correlation of output across countries, but a positive (negative) correlation of consumption (Obstfeld and Rogoff 1995, Betts and Devereux

\footnotetext{
${ }^{1}$ This literature includes Benigno and Benigno (2006), Devereux and Engel (2003), Duarte and Obstfeld (2008) as well as Gali and Monacelli (2005).
} 
2000). Under dollar pricing and a low cross-country substitutability, outputs are more highly correlated across countries than consumptions are, which is consistent with the empirical evidence. This result may be relevant with regards to the fact that virtually all U.S. trade is invoiced in dollars (Goldberg and Tille 2008), and short-term estimates of the cross-country substitutability in the U.S. are low (Hooper et al. 2000). The model can therefore explain a key fact in international business cycles using plausible assumptions and parameterization.

One of the main findings of this paper is that the value of the dollar peg is positive for the dollar bloc when U.S. interest rates fall. This provides a rationale for fixing the exchange rate to the dollar in the current environment. The positive value of the dollar peg stems from the ability of the U.S. to improve its terms of trade and consumption at the dollar bloc's expense under flexible exchange rates. The dollar peg prevents this, thereby increasing welfare. The dollar peg, however, has costs as well. As Rajan (2011) suggested, the combination of the dollar peg and aggressive U.S. monetary policy can lead to an overheating of the dollar bloc. In the model, the welfare cost of this is captured by a high variance of employment, which tends to decrease welfare. However, this welfare effect is offset by the positive effects.

Schnabl (2010) studies the costs and benefits of the dollar peg for China and East Asia and argues that it plays an important role in the pursuit of macroeconomic stability in the current environment. This paper supports the view that the benefits exceed the costs, not because of macroeconomic stability, but despite the macroeconomic instability (higher output and inflation fluctuations) caused by the dollar peg.

The value of the dollar peg is negative for the U.S. if the expenditure switching effect is sufficiently weak. In such a case, U.S. monetary policy is a beggar-thy-neighbor policy since the U.S. can raise welfare by improving its terms of trade. The dollar peg prevents this, so its value for the U.S. is negative.

If the expenditure switching effect is sufficiently strong, then the value of the dollar peg is positive for the U.S. If the expenditure switching effect is strong and exchange rates are flexible, any welfare benefits from higher consumption are offset by welfare losses due to a high variance of employment. A strong shift in demand in the dollar bloc toward U.S. goods causes U.S. output to increase (a high variance of employment). The dollar peg eliminates the expenditure switching effect and reduces the variance of employment, thus improving welfare. The deterioration of U.S. terms of trade, compared to the flexible exchange rate case, reduces welfare, but this effect is overshadowed by the welfare benefit of a lower variance of employment. The results show, however, that for the quite realistic parameter combinations of 
the cross-country elasticity and the Calvo parameter, the value of the dollar peg is negative for the U.S. This provides a novel rationale for criticism of China's exchange rate policy.

As mentioned, I also address the consequences of the dollar peg for the effectiveness of U.S. monetary policy. Measured by the cumulative change in output after 10 quarters, the dollar peg, by eliminating the expenditure switching effect, reduces the ability of U.S. monetary policy to stimulate output by $31 \%$ under benchmark parameterization, when compared cases where the dollar bloc adheres to the Taylor rule. This result is in sharp contrast with that of Erceg et al. (2011), who find that the effectiveness of U.S. monetary policy is nearly invariant to assumptions about the dollar bloc's monetary policy.

The rest of the paper is organized as follows: Section 2 introduces the model, Section 3 discusses the parameterization of the model, Section 4 analyses the international transmission of U.S. monetary policy and the value of the dollar peg, and Section 5 concludes the paper.

\section{Model}

In this section, I develop a New Keynesian open-economy model in which the world economy consists of two countries: the U.S. and the dollar bloc. The dollar bloc refers to economies that have pegged their currencies to the U.S. dollar. A continuum of firms and households are indexed by $z \in[0,1]$. Fraction $n$ of them are located in the U.S., while fraction $1-n$ are located in the dollar bloc.

Each firm produces a differentiated good, and nominal price rigidity is introduced via the mechanism proposed by Calvo (1983). Empirical evidence points to the asymmetry in international price setting. Goldberg and Tille (2008) find that $99.8 \%(92.8 \%)$ of U.S. exports (imports) are invoiced in dollars. I assume that U.S. firms set a unified price across countries and set their export prices in dollars. Firms in the dollar bloc can "price-to-market" and set their export prices in dollars. The assumption of asymmetric export pricing implies that the exchange rate pass-through is zero in the U.S. and one in the dollar bloc for those goods whose prices cannot be adjusted. In presenting the model that follows, if the equations are symmetric across countries, I present only the U.S. equation. 


\subsection{Households}

\subsubsection{Preferences}

All households have identical preferences. The utility function of the representative U.S. household is given by

$$
U_{t}(z)=E_{t} \sum_{s=t}^{\infty} \beta^{s-t}\left[\log C_{s}-\frac{\left(\ell_{s}(z)\right)^{2}}{2}\right],
$$

where $E$ denotes the expectation operator, $\beta$ is the discount factor, $C_{t}$ is a consumption index and $\ell_{t}(z)$ is the labour supply. The consumption index is given by

$$
C_{t}=\left[n^{\frac{1}{\rho}}\left(C_{t}^{U S}\right)^{\frac{\rho-1}{\rho}}+(1-n)^{\frac{1}{\rho}}\left(C_{t}^{D B}\right)^{\frac{\rho-1}{\rho}}\right]^{\frac{\rho}{\rho-1}},
$$

where $C_{t}^{U S}$ and $C_{t}^{D B}$ respectively denote U.S. household consumption of U.S. and the dollar bloc's goods, and $\rho>0$ measures the elasticity of substitution between U.S. and the dollar bloc's goods. I refer to $\rho$ as the cross-country substitutability. Consumption of domestic $C_{t}^{U S}(z)$ and foreign $C_{t}^{D B}(z)$ goods are CES aggregates of the different brands of U.S. and the dollar bloc's goods

$C_{t}^{U S}=\left[n^{-\frac{1}{\theta}} \int_{0}^{n}\left(C_{t}^{U S}(z)\right)^{\frac{\theta-1}{\theta}} d z\right]^{\frac{\theta}{\theta-1}}, \quad C_{t}^{D B}=\left[(1-n)^{-\frac{1}{\theta}} \int_{n}^{1}\left(C_{t}^{D B}(z)\right)^{\frac{\theta-1}{\theta}} d z\right]^{\frac{\theta}{\theta-1}}$,

where $\theta>1$ is the elasticity of substitution between goods produced in the same country.

The consumption indexes imply that households allocate their consumption according to the following equations:

$$
\begin{gathered}
C_{t}^{U S}(z)=\left[\frac{p_{t}^{U S}(z)}{P_{t}^{U S}}\right]^{-\theta}\left[\frac{P_{t}^{U S}}{P_{t}}\right]^{-\rho} C_{t}, \quad C_{t}^{D B}(z)=\left[\frac{p_{t}^{D B}(z)}{P_{t}^{D B}}\right]^{-\theta}\left[\frac{P_{t}^{D B}}{P_{t}}\right]^{-\rho} C_{t}, \\
C_{t}^{* U S}(z)=\left[\frac{p_{t}^{* U S}(z)}{P_{t}^{* U S}}\right]^{-\theta}\left[\frac{P_{t}^{* U S}}{P_{t}^{*}}\right]^{-\rho} C_{t}^{*}, \quad C_{t}^{* D B}(z)=\left[\frac{p_{t}^{* D B}(z)}{P_{t}^{* D B}}\right]^{-\theta}\left[\frac{P_{t}^{* D B}}{P_{t}^{*}}\right]^{-\rho} C_{t}^{*} .
\end{gathered}
$$

In these equations, asterisks indicate the dollar bloc's variables. Therefore, $C_{t}^{* U S}(z)$ and $C_{t}^{* D B}(z)$ respectively denote consumption of the differentiated U.S. and the dollar bloc's goods by the dollar bloc's households. All price indexes are expressed in the local currency, although U.S. firms set their export prices in dollars. Price $p$ represents dollar prices, and price $p^{*}$ represents foreign currency prices. The dollar price of U.S. and the dollar bloc's goods are denoted by $p_{t}^{U S}(z)$ and $p_{t}^{D B}(z)$, respectively. $p_{t}^{* U S}(z)$ and $p_{t}^{* D B}(z)$ are, 
respectively, the foreign currency price of U.S. and the dollar bloc's goods. $P_{t}^{U S}\left(P_{t}^{D B}\right)$ is the price indexes corresponding to U.S. (the dollar bloc's) consumption basket $C_{t}^{U S}\left(C_{t}^{D B}\right)$, and $P_{t}$ is the U.S. price index.

The U.S. price indexes are defined as follows:

$$
\begin{gathered}
P_{t}^{U S}=\left[n^{-1} \int_{0}^{n} p_{t}^{U S}(z)^{1-\theta} d z\right]^{\frac{1}{1-\theta}}, \quad P_{t}^{D B}=\left[(1-n)^{-1} \int_{n}^{1} p_{t}^{D B}(z)^{1-\theta} d z\right]^{\frac{1}{1-\theta}} \\
P_{t}=\left[n\left(P_{t}^{U S}\right)^{1-\rho}+(1-n)\left(P_{t}^{D B}\right)^{1-\rho}\right]^{\frac{1}{1-\rho}}
\end{gathered}
$$

The corresponding indexes for the dollar bloc are defined similarly.

\subsubsection{Budget constraints and financial markets}

Consider a cashless economy in which money is only a unit of account. The budget constraint of the typical U.S. household, in nominal terms, is given by

$$
D_{t}=\left(1+i_{t-1}\right) D_{t-1}+w_{t} \ell_{t}-P_{t} C_{t}+\pi_{t} .
$$

$D_{t}$ denotes nominal bonds (that pay one dollar in period $t+1$ ) held at the beginning of period $t, i_{t-1}$ is the nominal interest rate on bonds between $t-1$ and $t, w$ is the nominal wage paid to the household, and $\pi$ denotes the household's share of the nominal profits (dividends) of U.S. firms. All U.S. (dollar bloc) households own an equal share of all U.S. (dollar bloc) firms.

The structure of the dollar bloc is identical to that of the U.S. economy, with one exception: U.S. households can hold only U.S. bonds, whereas households in the dollar bloc can hold both U.S. and dollar bloc bonds. Therefore, the foreign bond $\left(F^{*}\right)$, denominated in the currency of the dollar bloc, is not traded internationally.

The budget constraint of a representative household in the dollar bloc is

$$
\frac{D_{t}^{*}}{S_{t}}+F_{t}^{*}=\left(1+i_{t-1}\right) \frac{D_{t-1}^{*}}{S_{t}}+\left(1+i_{t}^{*}\right) F_{t-1}^{*}+w_{t}^{*} \ell_{t}^{*}-P_{t}^{*} C_{t}^{*}+\pi_{t}^{*}
$$

The global asset market-clearing condition for U.S. bonds requires $n D_{t}+$ $(1-n) D_{t}^{*}=0$. The net supply of foreign bonds, on the other hand, is zero, because the dollar bloc has only one representative household.

Use of the Taylor rule implies that the model must be stationary. One way to render the model stationary is to assume that the domestic interest rate is increasing in the level of net foreign debt (Schmitt-Grohe and Uribe 2003). I include a risk premium for uncovered interest rate parity (UIP) that forces external debt in the long term to return to its initial level. Following Bergin (2006), I assume that lenders demand a higher rate of return on a country 
with large external debt. This view is supported by the empirical evidence: highly indebted countries have higher real interest rates than do countries with more positive external positions (Lane 2011). In addition, Bluedorn and Bowdler (2011) show that U.S. interest rate shocks cause deviations from UIP.

Households in the dollar bloc must be indifferent to holding U.S. or the dollar bloc bonds. The log-linear version of UIP with a risk premium $(\psi)$ can be expressed as

$$
(1-\beta) \hat{\imath}_{t}=(1-\beta) \hat{\imath}_{t}^{*}+E_{t} \hat{S}_{t+1}-\hat{S}_{t}-\psi \hat{D}_{t}
$$

where percentage changes from the initial steady state (denoted by the subscript zero) are denoted by hats (e.g., $\hat{\imath}_{t}=d i_{t} / i_{0}$ ). Equation (6) shows that households must pay a small cost if its bond holdings do not equal their initial steady-state level (i.e., zero).

The optimal behavior of households is governed by the following equations:

$$
\begin{aligned}
E_{t}\left(P_{t+1} C_{t+1}\right) & =\beta\left(1+i_{t}\right) P_{t} C_{t}, \\
E_{t}\left(P_{t+1}^{*} C_{t+1}^{*}\right) & =\beta\left(1+i_{t}^{*}\right) P_{t}^{*} C_{t}^{*}, \\
\ell_{t}(z) & =\frac{w_{t}}{C_{t} P_{t}}, \\
\ell_{t}^{*}(z) & =\frac{w_{t}^{*}}{C_{t}^{*} P_{t}^{*}} .
\end{aligned}
$$

Equations (7) and (8) are the Euler equations for optimal domestic and foreign consumption, respectively. Equations (9) and (10) show that the labour supply is an increasing function of real wages and a decreasing function of consumption.

\subsection{Monetary policy}

The U.S. central bank follows the log-linear Taylor rule with interest rate smoothing:

$$
\hat{\imath}_{t}=\left(1-\mu_{1}\right)\left(\mu_{2} \Delta \hat{P}_{t}+\mu_{3} \hat{y}_{t}\right)+\mu_{1} \hat{\imath}_{t-1}+\epsilon_{t},
$$

where coefficients $\mu_{1}, \mu_{2}$ and $\mu_{3}$ are non-negative, $\Delta$ is the first difference operator, and $\epsilon_{t}$ is an unpredictable shift in the monetary policy rule (zero mean white noise process). Equation (11) shows that the inflation target is zero. The output gap is defined as the deviation of output from the equilibrium level that would prevail in the absence of nominal rigidities. In this paper, I analyze the effects of monetary policy and therefore the deviation of output from the initial level measures the output gap. 
To evaluate the consequences of the dollar peg, I contrast the flexible exchange rate case in which the central bank of the dollar bloc follows the Taylor rule, which is identical to (11), with an alternative in which the central bank pegs the exchange rate. Erceg et al. (2011) use this same approach. For simplicity, I assume that the central bank of the dollar bloc pegs the exchange rate by mimicking U.S. monetary policy $\left(\hat{\imath}_{t}=\hat{\imath}_{t}^{*}\right)$.

A typical view is that most dollar bloc countries are to some extent forced to follow U.S. monetary policy. Rogoff (2008) pointed out that during the U.S. financial crisis, "[d]ollar bloc countries have slavishly mimicked expansionary US monetary policy". However, the question of whether China has been able to implement independent monetary policy is complicated. Koivu (2009) points out that China's monetary policy has relied on a fixed exchange rate, capital controls and a selection of administrative and quantitative policy tools. Ma and McCauley (2008) find that capital controls have proved effective. Cheung et al. (2008) find that U.S. interest rates have a weak effect on China. They argue that even with the dollar peg, China employs measures to retain its monetary policy independence.

Koivu (2009) points out that many features of China's monetary policy have changed in recent years. First, the role of interest rates has increased. In 2006-2007, the central bank increased the use of interest rates in an attempt to keep rising inflation under control. Second, since the summer of 2003, growing capital inflows have increased liquidity in China's financial markets and have complicated the conduct of monetary policy (Koivu 2009). Glick and Hutchison (2009) and Prasad (2008) find that the fixed exchange rate constrains China's monetary policy independence. Zhang (2009) shows that although money supply has been a dominant policy instrument in China in the past decades, a Taylor with interest rate smoothing that responses to the output gap and contemporary and expected inflation illustrates China's more recent monetary policy well.

Frankel (2010) finds that in 2007-2008, sterilization finally faltered and money growth became excessive. Bordo et al. (2012) find that China's sterilized foreign-exchange intervention fails to provide the central bank with a mechanism for systematically altering the exchange rate independently of its monetary policy. Moreover, Wolf (2008) argues that "Ben Bernanke is running the monetary policy of the People's Bank of China." Although the assumption that China follows U.S. monetary policy is a poor reflection of reality, it nonetheless provides a simple way to peg the currency to the dollar. 


\subsection{Firms}

\subsubsection{Profits}

All firms produce a differentiated good. The production function of the representative U.S. firm is

$$
y_{t}(z)=\ell_{t}(z)
$$

where $y_{t}(z)$ is the total output of firm $z$, and $\ell_{t}(z)$ is the labour input that firm $z$ uses.

The profits of the U.S. firm are given by

$$
\pi_{t}(z)=p_{t}^{U S}(z) y_{t}^{d}(z)-w_{t} \ell_{t}(z)
$$

The firm takes into account the production function (13) and the demand curve for its products

$$
y_{t}^{d}(z)=\left[\frac{p_{t}^{U S}(z)}{P_{t}^{U S}}\right]^{-\theta}\left[\frac{P_{t}^{U S}}{P_{t}}\right]^{-\rho} n C_{t}+\left[\frac{p_{t}^{U S}(z)}{P_{t}^{U S}}\right]^{-\theta}\left[\frac{P_{t}^{U S}}{S_{t} P_{t}^{*}}\right]^{-\rho}(1-n) C_{t}^{*} .
$$

The profits of the U.S. firm, therefore, can be written as

$$
\begin{aligned}
\pi_{t}(z)= & \left(p_{t}^{U S}(z)-w_{t}\right) \times \\
& {\left[\left[\frac{p_{t}^{U S}(z)}{P_{t}^{U S}}\right]^{-\theta}\left[\frac{P_{t}^{U S}}{P_{t}}\right]^{-\rho} n C_{t}+\left[\frac{p_{t}^{U S}(z)}{P_{t}^{U S}}\right]^{-\theta}\left[\frac{P_{t}^{U S}}{S_{t} P_{t}^{*}}\right]^{-\rho}(1-n) C_{t}^{*}\right] }
\end{aligned}
$$

As mentioned in Section 2, firms in the dollar bloc can "price-to-market" and set their prices in the currency of the buyer. The total output of the representative firm in the dollar bloc, $y_{t}^{*}(z)$, is divided between the output sold in the U.S., $v_{t}^{*}(z)$, and the output sold in the dollar bloc, $x_{t}^{*}(z)$. Its profits are given by

$$
\pi_{t}^{*}(z)=\left(p_{t}^{D B}(z) v_{t}^{*}(z)\right) / S_{t}+p_{t}^{* D B}(z) x_{t}^{*}(z)-w_{t}^{*} \ell_{t}^{*}(z) .
$$

The demand for the dollar bloc's goods are given by

$$
\begin{gathered}
v_{t}^{*}(z)=\left[\frac{p_{t}^{D B}(z)}{P_{t}^{D B}}\right]^{-\theta}\left[\frac{P_{t}^{D B}}{P_{t}}\right]^{-\rho} n C_{t}, \\
x_{t}^{*}(z)=\left[\frac{p_{t}^{* D B}(z)}{P_{t}^{* D B}}\right]^{-\theta}\left[\frac{P_{t}^{* D B}}{P_{t}^{*}}\right]^{-\rho}(1-n) C_{t}^{*} .
\end{gathered}
$$

Equations (16) and (17) show demand in the U.S. and in the dollar bloc, respectively. 


\subsubsection{Price setting}

U.S. firms maximize their profits, specified in Equation (14), with respect to $p_{t}^{U S}(z)$. In the absence of price rigidities, this would imply

$$
p_{t}^{U S}(z)=\frac{\theta}{\theta-1} w_{t} .
$$

Under the Calvo pricing assumption, each firm may reset its price in any given period with a probability of $1-\gamma$, independently of other firms and the elapsed time since the last adjustment. When setting a new price in period $t$, the firm seeks to maximize the discounted present value of expected real profits

$$
\max _{p_{t}^{U S}(z)} V_{t}(z)=E_{t} \sum_{s=t}^{\infty} \gamma^{s-t} Q_{t, s} \frac{\pi_{s}(z)}{P_{s}}
$$

where $Q_{t, s}$ is a stochastic discount factor between periods $t$ and $s$. The U.S. firm's optimization problem results in the following pricing rule:

$$
p_{t}^{U S}(z)=\left(\frac{\theta}{\theta-1}\right) \frac{E_{t} \sum_{s=t}^{\infty} \gamma^{s-t} Q_{t, s} A_{s} w_{s}}{E_{t} \sum_{s=t}^{\infty} \gamma^{s-t} Q_{t, s} A_{s}}
$$

where

$$
A_{s}=\left(\frac{1}{P_{s}^{U S}}\right)^{-\theta}\left(\frac{P_{s}^{U S}}{P_{s}}\right)^{-\rho}\left(\frac{n C_{s}}{P_{s}}\right)+\left(\frac{1}{P_{s}^{U S}}\right)^{-\theta}\left(\frac{P_{s}^{U S}}{E_{s} P_{s}^{*}}\right)^{-\rho}\left(\frac{(1-n) C_{s}^{*}}{P_{s}}\right) .
$$

The log-linear version of Equation (19) can be written as

$$
\hat{p}_{t}^{U S}(z)=\beta \gamma E_{t} \hat{p}_{t+1}^{U S}(z)+(1-\beta \gamma) \hat{w}_{t} .
$$

The optimal price is the weighted average of current and future nominal marginal costs.

The representative firm in the dollar bloc seeks to maximize

$$
\max _{p_{t}^{D B}(z), p_{t}^{* D B}(z)} V_{t}^{*}(z)=E_{t} \sum_{s=t}^{\infty} \gamma^{s-t} Q_{t, s}^{*} \frac{\pi_{s}^{*}(z)}{P_{s}^{*}} .
$$

The pricing rules are given by

$$
p_{t}^{D B}(z)=\left(\frac{\theta}{\theta-1}\right) \frac{E_{t} \sum_{s=t}^{\infty} \gamma^{s-t} Q_{t, s}^{*}\left(\frac{C_{s}}{P_{s}}\right)\left(\frac{1}{P_{s}^{D B}}\right)^{-\theta}\left(\frac{P_{s}^{D B}}{P_{s}}\right)^{-\rho} w_{s}^{*}}{E_{t} \sum_{s=t}^{\infty} \gamma^{s-t} Q_{t, s}^{*}\left(\frac{C_{s}}{P_{s}}\right)\left(\frac{1}{P_{s}^{D B}}\right)^{-\theta}\left(\frac{P_{s}^{D B}}{P_{s}}\right)^{-\rho}\left(\frac{1}{S_{s}}\right)},
$$




$$
p_{t}^{* D B}(z)=\left(\frac{\theta}{\theta-1}\right) \frac{E_{t} \sum_{s=t}^{\infty} \gamma^{s-t} Q_{t, s}^{*}\left(\frac{C_{s}}{P_{s}}\right)\left(\frac{1}{P_{s}^{D B}}\right)^{-\theta}\left(\frac{P_{s}^{D B}}{P_{s}}\right)^{-\rho} w_{s}^{*}}{E_{t} \sum_{s=t}^{\infty} \gamma^{s-t} Q_{t, s}^{*}\left(\frac{C_{s}}{P_{s}}\right)\left(\frac{1}{P_{s}^{* D B}}\right)^{-\theta}\left(\frac{P_{s}^{* D B}}{P_{s}}\right)^{-\rho}} .
$$

The log-linear versions of these equations can be expressed as

$$
\begin{gathered}
\hat{p}_{t}^{D B}(z)=\beta \gamma E_{t} \hat{p}_{t+1}^{D B}(z)+(1-\beta \gamma)\left(\hat{w}_{t}^{*}+S_{t}\right) . \\
\hat{p}_{t}^{* D B}(z)=\beta \gamma E_{t} \hat{p}_{t+1}^{* D B}(z)+(1-\beta \gamma) \hat{w}_{t}^{*} .
\end{gathered}
$$

Equation (22) shows that the optimal price of the dollar bloc's good sold in the U.S. is the weighted average of current and future nominal marginal costs and the exchange rate.

\subsection{Symmetric equilibrium}

Consider a symmetric case in which every firm that changes its price in any given period chooses the same price and output. This implies that in each period, a fraction of firms $(1-\gamma)$ sets a new price, and the price of the remaining fraction remains unchanged.

The consolidated budget constraint of the home economy is derived with Equations (4) and (13):

$$
P_{t} C_{t}=p_{t}^{U S}(z) y_{t}(z)+\left(1+i_{t-1}\right) D_{t-1}-D_{t} .
$$

The corresponding foreign equation, which takes into account the global asset market-clearing condition for U.S. bonds and that the net supply of the bond in the dollar bloc is zero, is

$P_{t}^{*} C_{t}^{*}=\left(p_{t}^{D B}(z) v_{t}^{*}(z)\right) / S_{t}+p_{t}^{* D B}(z) x_{t}^{*}(z)-\left(1+i_{t-1}\right) \frac{n}{1-n} \frac{D_{t-1}}{S_{t}}+\frac{n}{1-n} \frac{D_{t}}{S_{t}}$.

I use a log-linearized version of the model around a symmetric steady state in which initial net foreign assets are zero $\left(D_{0}=0\right)$. Equations $(9)$, (12) and (18) imply that the initial level of employment is given by

$$
y_{0}=\ell_{0}=\left(\frac{\theta-1}{\theta}\right)^{\frac{1}{2}}
$$

Equilibrium is defined as sequences of variables that clear the labour and goods markets in both countries every period and satisfy pricing rules and intertemporal budget constraints. 


\section{Parameter values}

The parameterization of the model is chosen to match features of the U.S. and the dollar bloc. Periods are interpreted as quarters. The discount factor $\beta$ is set to 0.99 , which implies a steady state real interest rate of about $4 \%$. As mentioned in Section 2, The Economist (2011) found that the dollar bloc's collective GDP was almost 9 trillion dollars at that time. U.S. GDP was roughly 14 trillion dollars at that time. Consequently, the relative size of the U.S. economy $(n)$ is set to 0.6. In comparison, Erceg et al. (2011) set the size of the U.S. economy relative to the dollar bloc to 0.55 , but argue that their parameterization overstates the size of the dollar bloc.

The interest rate smoothing parameter $\left(\mu_{1}\right)$ is set to 0.79 , which is consistent with Clarida et al. (2000). Based on Taylor (1993), $\mu_{2}$ is set to 1.5 and $\mu_{3}$ is set to $0.5 / 4$. Zhang (2009) finds that before China returned to the dollar peg in mid-2008 the interest rate smoothing parameter was 0.76 and the weight of inflation (the annual output gap) was 0.94 (0.47). Therefore, the Taylor rule with interest rate smoothing is not unrealistic description of monetary policy in China.

Based on Bergin (2006), the risk premium in UIP $(\psi)$ is set to 0.004 . This implies that a net foreign debt of $10 \%$ of output increases the domestic interest rate by four basis points relative to that of the foreign country. Based on Rotemberg and Woodford (1992), the within-country substitutability $(\theta)$ is set to 6 . This value is widely used in the business cycle literature.

In this paper, I analyze the consequences of the dollar peg for the ability of U.S. monetary policy to stimulate output. The price rigidity parameter $(\gamma)$ is therefore a key parameter for the question at hand, because it governs the strength and duration of the expenditure switching effect. Consequently, it is important to set the parameter to match the empirical evidence on the price rigidities of internationally traded goods. Gopinath and Rigobon (2008) find that the trade-weighted median price duration is 12.8 (10.6) months for U.S. exports (imports). I therefore set $\gamma$ to 0.75 , which implies that an average delay between price adjustments of four quarters.

The cross-country substitutability $\rho$ is another key parameter for the theme of this paper. Tille (2001) shows that it is a key parameter in determining the international welfare effects of monetary policy. It also influences the strength of the expenditure switching effect. Using U.S. data, Broda and Weinstein (2006) find that the median estimate of the cross-country substitutability ranges between 2.3 and 3.7, depending on the aggregation level and time period. Feenstra et al. (2011) find that the median estimate of the micro elasticity (substitution between different import suppliers) between U.S. and foreign countries is roughly 3, while the macro elasticity (substi- 
tution between home production and imports) does not significantly differ from unity.

Hooper et al. (2000) estimate the short- and long-term price elasticities of exports and imports for G7 countries. They find that the sum of the short-term elasticities for imports and exports exceeds one in absolute value only in the U.S. For the U.S. it is 1.1; for Japan, it is 0.6. The elasticities, however, increase over time and typically exceed one in the long term. The sum of the long-term elasticities for the U.S. is 1.8; for Japan, it is 1.3.

I set $\rho$ to 2 , which is the average of the estimates for the U.S. provided by Broda and Weinstein (2006), Feenstra et al. (2011) and Hooper et al. (2000). However, I analyze the sensitivity of key results using the values 0.5 , $1,3,4,6$ and $9 .^{2}$

\section{International transmission of U.S. mone- tary policy}

\subsection{U.S. monetary policy under flexible exchange rates}

The main innovation of this paper is to evaluate the value of the dollar peg relative to the flexible exchange rate. Therefore, I begin by analyzing the international effects of a U.S. interest rate cut under flexible exchange rates. Many of these results are not relevant per se; they provide a useful benchmark to put into context the results of the following section.

The dynamic effects of this exercise appear in panels (a)-(h) of Figure 1 (on page 31). In all figures, the horizontal axis denotes time. The vertical axis typically shows percentage deviations from the initial steady state. ${ }^{3}$ The responses of inflation and interest rates, however, are expressed as percentage point deviations in annual terms. The U.S. terms of trade, shown in Figure 1(d), are defined as the Calvo-weighted relative price of U.S. exports in terms of U.S. imports. If the index rises, the U.S. terms of trade improve.

Figure 1(e) shows that I analyze the effects of a decrease of 25 basis points (bp) in the annual U.S. interest rate (i.e. the annual interest rate is lowered from roughly $4 \%$ to $3.75 \%$ ). The 25 basis point reduction in the interest rate might not seem to be a realistic description of the response of the Fed to the crisis: the interest rate was driven all the way to zero and the Fed has indicated that it will pursue the zero rate interest policy for a long time. The Fed, however, has typically adjusted the interest rate gradually, in a series of

\footnotetext{
${ }^{2}$ I solve the model using the algorithm developed by Klein (2000) and McCallum (2001).

${ }^{3}$ The change in bond holding, whose initial steady state is zero, is expressed as a deviation form initial consumption.
} 
25 or 50 basis point steps in the same direction. The Fed's recent monetary policy can, therefore, seen as a series of 25 basis points reductions in the policy rate.

Figure 1(c) demonstrates that a U.S. interest rate reduction depreciates the nominal exchange rate. The U.S. interest rate is temporarily low relative to the dollar bloc's interest rate. Since UIP holds, the exchange rate must depreciate to a point where it will appreciate until it reaches the steady-state level.

In the dollar pricing case, the exchange rate pass-through to import price is one in the dollar bloc and zero in the U.S for those goods whose prices cannot be adjusted. In the dollar bloc, the dollar's depreciation implies that U.S. goods become cheaper relative to the dollar bloc's goods. This shifts demand toward U.S. goods and away from the dollar bloc's goods. This expenditure switching effect increases U.S. output and tends to decrease the dollar bloc's output. Due to a low cross-country substitutability, this effect is relatively weak and dominated by the direct demand increase of U.S. households. The exchange rate pass-through is zero in the U.S., and a rise in U.S. demand increases both U.S. and the dollar bloc's output. Output, therefore, also increases in the dollar bloc in the short term.

A low interest rate raises consumption in both regions. In the dollar pricing case, the dollar's depreciation reduces the dollar bloc's earnings in its own currency (see Equation (15)). This and the expenditure switching effect increase relative U.S. consumption. U.S. households smooth consumption over time and save part of this income by running a current account surplus in the short term (Figure $1(\mathrm{~g})$ ). The risk premium in UIP compels bond holdings of the U.S. households to return to the initial level in the long term. They therefore use accumulated wealth to finance consumption and bond holdings begins to wane.

The next step is to implement welfare analysis. Following Schmitt-Grohe and Uribe (2007), it has become common to evaluate the welfare cost of policy A relative to policy $\mathrm{B}$, expressing the welfare difference in the percentage of consumption that households are willing to give to be as well off under policy A as under policy B. Later in this paper, I evaluate the value of the dollar peg as the percentage of consumption that households would be willing to pay for the dollar peg in order to be as well off under the dollar peg as under a floating exchange rate. To measure welfare in an identical way under flexible exchange rates, I now measure the welfare benefit of monetary policy as the percentage of consumption that households would be willing to pay for U.S. monetary expansion to remain as well off in the monetary expansion case as in the initial steady state.

As shown in Tervala (2012), the discounted present value (DPV) of the 
welfare benefit of monetary policy relative to the initial steady state, denoted by $\lambda_{D P V}$, is given by:

$$
\lambda_{D P V}=100 \times\left[\exp \left((1-\beta)\left(\sum_{s=t}^{\infty} \beta^{s-t}\left(\hat{C}_{s}-\ell_{0}^{2} \hat{\ell}_{s}-\ell_{0}^{2} \hat{\ell}_{s}^{2}\right)\right)-1\right] .\right.
$$

Equation (25) measures the percentage of initial consumption that the household is willing to pay for monetary policy expansion.

Table 1: Welfare effects under flexible exchange rates

\begin{tabular}{|l|l|l|l|l|l|l|l|}
\hline & $\rho=0.5$ & $\rho=1$ & $\rho=2$ & $\rho=3$ & $\rho=4$ & $\rho=6$ & $\rho=9$ \\
\hline$\lambda_{D P V}$ & 0.10 & 0.11 & 0.071 & 0.025 & -0.019 & -0.11 & -0.24 \\
\hline$\lambda_{D P V}^{*}$ & -0.29 & -0.42 & -0.58 & -0.70 & -0.80 & -0.93 & -1.1 \\
\hline
\end{tabular}

Table 1 shows the welfare effects in the benchmark case $(\rho=2)$ and when using a set of alternative parameter values for the cross-country substitutability. It demonstrates that in the basic case, a U.S. interest rate reduction is a beggar-thy-neighbor policy that increases U.S. welfare at the dollar bloc's expense. The welfare benefit for U.S. households is $0.071 \%$ for their initial consumption.

Equation (25) shows that welfare in an increasing function of the level of consumption and a decreasing function of the level and the variance of employment. A U.S. terms of trade improvement explains the beggar-thyneighbor welfare result. Monetary expansion increases in U.S. consumption with no equivalent increase in employment. As Figure 1(d) shows, the U.S. terms of trade improve even though prices for both U.S. exports and imports are set in dollars. In the short term, some firms can set a new price, and the relative increase in the demand curve for U.S. firms allows them to raise the relative price of their goods. Thus, U.S. terms of trade improve. This effect dominates the welfare loss that results from the variance of employment. The drop in the dollar bloc's welfare stems from a deterioration of its terms of trade and the variance of employment.

Table 1 shows that a decrease in the dollar bloc's welfare is a robust finding. A high cross-country substitutability implies a decrease in U.S. welfare, however. In this case, a stronger expenditure switching effect in the dollar bloc increases U.S. employment, and when compared to the benchmark case, a higher variance of U.S. employment reduces welfare. If the crosscountry substitutability is high, the welfare losses resulting from the variance of employment dominate the welfare benefit that stems from improved term of trade. 
The finding that the welfare effects of monetary policy under dollar pricing depend qualitatively on the cross-country substitutability does not appear in the literature. Schmidt (2006) finds that a money supply shock is a beggar-thy-neighbor policy under dollar pricing. This paper, however, shows that this result is not generally applicable. The results differ for two reasons: Schmidt (2006) sets the cross-country substitutability to 1.5 and uses a first-order approximation of the utility function. This paper shows that a second-order term related to the variance of employment is qualitatively important for welfare in cases of a high cross-country substitutability. If I use a first-order approximation of the utility function in equation (25), I will also find a positive welfare effect in cases of a high cross-country substitutability. Thus, the high variance of employment explains the decrease in U.S. welfare in cases of a high cross-country substitutability.

Backus et al. (1992) show that the positive correlation of output between the U.S. and foreign countries is greater than the positive correlation of consumption between the U.S. and foreign countries. Providing for these observations has posed a challenge for models. In the producer (local) currency pricing case, a monetary shock generates a negative (positive) correlation of output across countries, but a positive (negative) correlation of consumption (Obstfeld and Rogoff 1995, Betts and Devereux 2000). Schmidt (2006) shows that under dollar pricing, both outputs and consumptions are positively correlated across countries. She, however, finds that consumptions more highly correlate across countries than outputs. This is the outcome in this model also.

The above discussion suggests that the cross-country substitutability affects the cross-country correlation of output because it governs the strength of the expenditure switching effect in the dollar bloc. The lower the elasticity, the weaker the expenditure switching. A low cross-country substitutability, therefore, increases the dollar bloc's output and reduces U.S. output. Consequently, the cross-country correlation of output increases when the crosscountry substitutability decreases.

Panels (i) and (j) of Figure 1 show the response of output and consumption in cases where the cross-country substitutability is one. In this case, measured by correlation coefficients, outputs are more highly correlated across countries than consumptions are, a result which is consistent with the empirical evidence. This result may be relevant to the fact that virtually all U.S. trade is invoiced in dollars (Goldberg and Tille 2008) and that shortterm estimates of the cross-country substitutability are close to one in the U.S. (Hooper et al. 2000). Thus, the model explains a key fact in international business cycles using plausible assumptions and parameterization. It is obvious that monetary shocks are not the sole cause of international busi- 
ness cycles, but the model can explain-in contrast with most open economy models-that the positive correlation of outputs is larger than the positive correlation of consumptions.

The literature contains cases where the cross-country correlations of output and consumption are in line with the empirical evidence. These results are typically based on the assumption that shocks correlate across countries. For instance, Corsetti et al. (2008) find that the positive correlation of output across countries arises mainly because of the positive correlation of innovation shocks across countries. This paper demonstrates that a combination of dollar pricing and a low cross-country substitutability can explain a stylized fact in case of a unilateral U.S. monetary shock.

\subsection{Value of the dollar peg}

In this section, I analyze a case in which the dollar bloc pegs the currency to the dollar. Figure 2 (on page 32) shows the effects of a U.S. interest rate shock identical to one discussed in the previous section. The solid lines show the effects under flexible exchange rates, and the dashed lines depict the effects in the dollar peg case.

The dollar bloc must now mimic U.S. monetary policy. Figure 2 does not show the U.S. interest rate, but panel (h) depicts an interest rate in the dollar bloc that is identical to the U.S. rate. An interest rate cut in both regions implies a larger monetary expansion. Consequently, world consumption and output increase more under the dollar peg than they would under flexible exchange rates.

The dollar peg eliminates movement in the nominal exchange rate (Figure 2(e)), thus eliminating the expenditure switching effect that increases relative U.S. output under flexible exchange rates. Consequently, U.S. output increases by less and the dollar bloc's output increases by more than they would under flexible exchange rates. An important implication for U.S. monetary policy is that the dollar peg substantially reduces the effectiveness of monetary policy. I measure the loss in the ability of U.S. monetary policy to stimulate output as follows: I calculate cumulative changes in output after ten quarters and then the percentage change caused by the dollar peg relative to the flexible exchange rate case. As before, I use the superscripts $P E G$ and $F$ to denote the dollar peg and floating exchange rate.

$$
\left(\frac{\sum_{t=1}^{10} \hat{y}_{t}^{P E G}-\sum_{t=1}^{10} \hat{y}_{t}^{F}}{\sum_{t=1}^{10} \hat{y}_{t}^{F}}\right) * 100 .
$$

Table 2 shows the loss in the ability of U.S. monetary policy to stimulate output in the short term. It shows that under the benchmark parameteriza- 
tion, the dollar peg reduces the cumulated increase in output by $31 \%$. Erceg et al. (2011) develop a three-country model (the U.S., the dollar bloc and the rest of the world) and find that (their Figure 4) the dollar peg reduces the ability of U.S. monetary policy to stimulate U.S. output relative to cases where the dollar bloc adheres to the Taylor rule. This finding is consistent with my finding, although Erceg et al. (2011) find that U.S. output is nearly invariant to assumptions about the dollar bloc's monetary policy. I instead find that the loss in the effectiveness of U.S. monetary policy is relatively high. The different result is likely due to the relatively low degree of openness of the U.S. economy in their model.

Table 2: Change in the effectiveness of U.S. monetary policy

\begin{tabular}{|l|l|l|l|l|l|l|}
\hline$\rho=0.5$ & $\rho=1$ & $\rho=2$ & $\rho=3$ & $\rho=4$ & $\rho=6$ & $\rho=9$ \\
\hline$-8 \%$ & $-19 \%$ & $-31 \%$ & $-38 \%$ & $-42 \%$ & $-49 \%$ & $-56 \%$ \\
\hline
\end{tabular}

The dollar peg eliminates a distribution of income toward the U.S. and thus monetary expansion does not increase relative U.S. income and U.S. households cannot accumulate external wealth (see Figure 2(g)) for future consumption. This implies that the risk premium in UIP plays no role in adjustment dynamics. An identical increase in outputs implies that the international price ratio does not change. Consequently, Figure 2(f) shows, the U.S. terms of trade remain constant. This result is important for welfare, because the increase in U.S. welfare under the flexible exchange rate is based on improved terms of trade.

Figure 2(b) demonstrates that, compared to the flexible exchange rate case, the dollar bloc's consumption increases. The dollar bloc's monetary expansion and the elimination of the expenditure switching effect imply a greater increase in the dollar bloc's output. In addition, the fact that the dollar bloc's terms of trade do not deteriorate increases the dollar bloc's consumption, in comparison to the flexible exchange rate case.

Table 3 shows that welfare increases equally in both the U.S. and the dollar bloc. They implement identical monetary expansion, consumption and employment increase equally, and the change in welfare therefore is identical.

Table 3: Welfare effects under the dollar peg

\begin{tabular}{|l|l|l|l|l|l|l|l|}
\hline & $\rho=0.5$ & $\rho=1$ & $\rho=2$ & $\rho=3$ & $\rho=4$ & $\rho=6$ & $\rho=9$ \\
\hline$\lambda_{D P V}$ & 0.0065 & 0.0065 & 0.0065 & 0.0065 & 0.0065 & 0.0065 & 0.0065 \\
\hline$\lambda_{D P V}^{*}$ & 0.0065 & 0.0065 & 0.0065 & 0.0065 & 0.0065 & 0.0065 & 0.0065 \\
\hline
\end{tabular}

The main innovation of this paper is to evaluate the value of the dollar peg, which I define as the percentage of consumption that households would be willing to pay for the dollar peg in order to be as well off under the dollar 
peg as under a floating exchange rate, assuming that labour supply remains constant.

Let $U_{D P V}^{F}$ be the DPV of welfare under floating exchange rates, and let $\left\{C_{s}^{F}, \ell_{s}^{F}(z)\right\}_{s=t}^{\infty}$ be associated the consumption and labour supply paths:

$$
U_{D P V}^{F}=\sum_{s=t}^{\infty} \beta^{s-t}\left[\log C_{s}^{F}-\frac{\left(\ell_{s}^{F}(z)\right)^{2}}{2}\right] .
$$

Let $U_{D P V}^{P E G}$ be the DPV of welfare under the dollar peg, and let us define $\lambda_{D P V}^{P E G}$ as the DPV of the welfare benefit of the dollar peg. $U_{D P V}^{F}$ can be written as follows:

$$
\begin{aligned}
U_{D P V}^{P E G} & =\sum_{s=t}^{\infty} \beta^{s-t}\left[\log \left(\left(1+\lambda_{D P V}^{P E G}\right) C_{s}^{F}\right)-\frac{\left(\ell_{s}^{F}(z)\right)^{2}}{2}\right], \\
U_{D P V}^{P E G} & =\frac{1}{1-\beta} \log \left(1+\lambda_{D P V}^{P E G}\right)+U_{D P V}^{F} .
\end{aligned}
$$

Solving for $\lambda_{D P V}^{P E G}$ and expressing the value of the dollar peg as the percentage of consumption (instead of a fraction of it) yields

$$
\lambda_{D P V}^{P E G}=100 \times\left[\exp (1-\beta)\left(U_{D P V}^{P E G}-U_{D P V}^{F}\right)-1\right] .
$$

Second-order approximations of the utility function are

$$
\begin{aligned}
& d U_{D P V}^{P E G}=U_{D P V}^{P E G}-U_{0}=\sum_{s=t}^{\infty} \beta^{s-t}\left(\hat{C}_{t}^{P E G}-\ell_{0}^{2} \hat{\ell}_{t}^{P E G}-\ell_{0}^{2}\left(\hat{\ell}_{t}^{P E G}\right)^{2}\right), \\
& d U_{D P V}^{F}=U_{D P V}^{F}-U_{0}=\sum_{s=t}^{\infty} \beta^{s-t}\left(\hat{C}_{t}^{F}-\ell_{0}^{2} \hat{\ell}_{t}^{F}-\ell_{0}^{2}\left(\hat{\ell}_{t}^{F}\right)^{2}\right)
\end{aligned}
$$

where the superscript $P E G$ and $F$ serve to denote the dollar peg and floating exchange rate. Making use of Equations (29) and (30), Equation (28) can be written as follows:

$$
\begin{aligned}
\lambda_{D P V}^{P E G}= & 100 \times\left[\operatorname { e x p } \left(( 1 - \beta ) \left(\sum_{s=t}^{\infty} \beta^{s-t}\left(\hat{C}_{s}^{P E G}-\ell_{0}^{2} \hat{\ell}_{s}^{P E G}-\ell_{0}^{2}\left(\hat{\ell}_{s}^{P E G}\right)^{2}\right)\right.\right.\right. \\
& \left.\left.-\left(\sum_{s=t}^{\infty} \beta^{s-t}\left(\hat{C}_{s}^{F}-\ell_{0}^{2} \hat{\ell}_{s}^{F}-\ell_{0}^{2}\left(\hat{\ell}_{s}^{F}\right)^{2}\right)\right)\right)-1\right]
\end{aligned}
$$

Equation (31) measures the value of the dollar peg as the percentage of consumption that the domestic household is willing to pay for the dollar peg in order to be as well off under the dollar peg as under the floating exchange rate. Consequently, a positive value for the dollar peg implies that households are better off under the dollar peg. 
Table 4: Value of the dollar peg

\begin{tabular}{|l|l|l|l|l|l|l|l|}
\hline & $\rho=0.5$ & $\rho=1$ & $\rho=2$ & $\rho=3$ & $\rho=4$ & $\rho=6$ & $\rho=9$ \\
\hline$\lambda_{D P V}^{P E G}$ & -0.096 & -0.10 & -0.065 & -0.019 & 0.030 & 0.12 & 0.25 \\
\hline$\lambda_{D P V}^{* P E G}$ & 0.30 & 0.43 & 0.59 & 0.71 & 0.81 & 0.95 & 1.1 \\
\hline
\end{tabular}

Table 4 shows that the value of the dollar peg is negative for the U.S. when the cross-country elasticity is sufficiently low. U.S. households are willing to pay part of their consumption to eliminate the dollar peg. On the other hand, the households in the dollar bloc are always better off under the dollar peg. This provides a rationale for the dollar bloc to peg the currency to the U.S. dollar. To the best of my knowledge, these results are all new, since the existing literature contains no analyses of the value of the dollar peg relative to cases where countries adhere to the Taylor rule.

The positive value of the dollar peg for the dollar bloc stems from the ability of the U.S. to improve its terms of trade at the dollar bloc's expense. The dollar peg prevents this, and in essence renders the dollar bloc a closed economy: its consumption and output increase by equally. This increases welfare in the model. Due to imperfect competition, the levels of consumption and output are inefficiently low, and interest rate reductions bring them temporarily closer to an efficient level, thereby increasing welfare. The variance of employment, however, tends to decrease welfare, but this effect is more than offset by the positive effect. The positive value of the dollar peg comes from the fact that the dollar peg prevents the U.S. from deteriorating the dollar bloc's terms of trade and forces monetary expansion in the dollar bloc.

The value of the dollar peg is negative for the U.S. if the cross-country elasticity is low. In the case of the dollar peg, U.S. interest rate reductions do not raise U.S. consumption by improving its terms of trade. The dollar peg prevents the U.S. from improving its terms of trade at the dollar bloc's expense. Consequently, the dollar peg is harmful to the U.S. Table 3, however, shows that U.S. interest rate reductions increase welfare, but the value of the dollar peg is nonetheless negative.

As Table 4 shows, the value of the dollar peg is negative for the U.S. if the cross-country substitutability is high. In this case, the welfare benefits of higher consumption are offset by the welfare losses from a high variance of employment under flexible exchange rates. When the dollar bloc fixes their currencies to the dollar, U.S. monetary policy more weakly affects U.S. output and employment. This is because the dollar peg eliminates the expenditure switching effect in the dollar bloc that strongly increases U.S. employment if the cross-country substitutability is high. The dollar peg therefore reduces the variance of employment, which increases welfare. The deterioration of 
U.S. terms of trade (compared to the flexible exchange rate case) reduces welfare, but this effect is offset by the welfare benefit coming from a reduction in the variance of employment.

\subsection{Sensitivity analysis}

The above discussion suggests that employment depends on the strength of the expenditure switching effect that, in turn, is affected by the speed of price adjustment. This is important for welfare since the variance of employment is a key factor in welfare results. I therefore carry out a sensitivity analysis to assess whether the results regarding the value of the dollar peg are sensitive to a change in this parameter. The Calvo parameter is often set to 0.5 , implying an average delay of six months ( 2 periods) between price adjustments. This is consistent with the estimates of Bils and Klenow (2004), which are based on U.S. retail prices. Now prices are more flexible, so the expenditure switching effect becomes weaker and fades away faster.

Table 5 shows the welfare effects of U.S. monetary policy on U.S. welfare under flexible exchange rates. Table 6 shows the value of the dollar peg for the U.S. I focus exclusively on the U.S. because a change in the Calvo parameter does not affect (qualitatively) results for the dollar bloc. The second row of these tables show the results under the benchmark parameterization $(\gamma=$ 0.75 ) and the third row using a value of $\gamma=0.5$.

Table 5: Sign of the welfare effect under flexible exchange rates

\begin{tabular}{|l|l|l|l|l|l|l|l|}
\hline & $\rho=0.5$ & $\rho=1$ & $\rho=2$ & $\rho=3$ & $\rho=4$ & $\rho=6$ & $\rho=9$ \\
\hline$\lambda_{D P V}, \gamma=0.75$ & + & + & + & + & - & - & - \\
\hline$\lambda_{D P V}, \gamma=0.5$ & + & + & + & + & + & + & - \\
\hline
\end{tabular}

Table 5 shows that more flexible prices increase the threshold value of the cross-country substitutability required for a negative welfare effect. As discussed above, when the expenditure switching effect is strong (prices are sticky, and the cross-country substitutability is sufficiently high), the welfare losses from a high variance of employment offset the positive welfare effects of monetary policy. As prices become more flexible, the change in the international price ratio caused by the depreciation of the dollar is smaller and diminishes faster. Consequently, the expenditure switching weakens. A lower value for $\gamma$ substantially reduces the positive effects of monetary policy on U.S. output in cases where $\rho=6$. The detrimental effect of a high variance of employment therefore diminishes. In this case, a lower value for the Calvo parameter $(\gamma=0.5)$ leads to a qualitative change: the welfare losses of a variance of employment are now dominated by the welfare benefits of higher consumption. 
Table 6: Sign of the value of the dollar peg

\begin{tabular}{|l|l|l|l|l|l|l|l|}
\hline & $\rho=0.5$ & $\rho=1$ & $\rho=2$ & $\rho=3$ & $\rho=4$ & $\rho=6$ & $\rho=9$ \\
\hline$\lambda_{D P V}^{P E G}, \gamma=0.75$ & - & - & - & - & + & + & + \\
\hline$\lambda_{D P V}^{P E G}, \gamma=0.5$ & - & - & - & - & - & - & + \\
\hline
\end{tabular}

Table 6 shows that a change in the Calvo parameter leads to a qualitative change in the value of the dollar peg for the U.S. in cases where $\rho=4$ and $\rho=$ 6. As just noted, the harmful welfare effect of a high variance of employment is now more than offset by the welfare benefit of higher consumption. The U.S. can therefore increase its consumption by improving its terms of trade at the expense of the dollar bloc. The dollar peg eliminates this so the value of the dollar peg also becomes negative for the U.S. in cases where $\rho=4$ and $\rho=6$.

The benchmark economy for welfare comparisons is the one with the flexible exchange rate case, under which both countries follow a Taylor rule (TR, for short) with interest rate smoothing. This may be too narrow and it is interesting to use different monetary policy rules for the dollar bloc as a benchmark to examine the welfare benefits of the dollar peg. I analyze the consequences of three alternative monetary policy rule for the dollar bloc. The first rule is the Taylor without interest rate smoothing (TRw/oS, for short), i.e. $\mu_{1}=0$ in equation (11). The second is the inflation-based Taylor rule (ITR, for short) without interest rate smoothing, i.e. $\mu_{1}=\mu_{3}=0$. The third rule is the domestic inflation-based Taylor rule (DITR, for short) ${ }^{4}$

$$
\hat{\imath}_{t}^{*}=\mu_{2} \Delta \hat{P}_{t}^{* D B} .
$$

Table 7: Sensitivity analysis: the value of the dollar peg

\begin{tabular}{|l|l|l|l|l|}
\hline & TR & TRw/oS & ITR & DITR \\
\hline$\lambda_{D P G}^{P E G}$ & -0.065 & -0.065 & -0.064 & -0.064 \\
\hline$\lambda_{D P V}^{* P E G}$ & 0.59 & 0.59 & 0.59 & 0.59 \\
\hline
\end{tabular}

Table 7 shows the value of the dollar peg under the four different policy rules for the dollar peg in the case where the cross-country substitutability is two. The table shows that it is a robust finding that the dollar peg is harmful to the U.S. but beneficial for the dollar peg in the case of expansionary U.S. monetary policy. The dollar bloc's monetary policy rule has very limited impact on the value of the dollar peg. The main reason for this is that under all rules the response of the dollar bloc's central bank is very mild.

\footnotetext{
${ }^{4}$ Gali and Monacelli (2005) use the second and third rule to analyse monetary policy for a small open economy.
} 


\subsection{Discussion}

The positive value of the dollar peg for developing countries provides a rationale for fixing their currencies to the dollar during a period of aggressive U.S. monetary policy. It is worth noting that, while China has closely monitored the yuan's movements against the dollar, it has not always followed a tight dollar peg. China allowed mild fluctuations in the nominal exchange rate after 2005 until it returned to the pre-2005 tight dollar peg in mid-2008, when the Fed aggressively cut interest rates. This supports the view that, while the tight dollar peg may not be optimal all the time-especially when the Fed raises interest rates-it could be optimal when the Fed cuts interest rates aggressively.

The theme of this paper is related to a classic question of whether pegging a country's exchange rate is beneficial. Friedman (1953) finds that shocks require the adjustment of relative price levels between countries and that because internal prices are highly inflexible, the exchange rate should be flexible. Feldstein (1992) argues that domestic deflation is likely to require a period of increased unemployment, so a decline in the nominal exchange rate would prove beneficial. Devereux and Engel (2003, 766) argue that "[t]his reasoning has led to the well-known traditional recommendation to monetary policy makers in open economies: an optimal monetary policy in an open economy requires exchange-rate flexibility."

Since the publication of Obstfeld and Rogoff (2002), some studies have analyzed the optimal choice of the exchange rate regime in the face of nonmonetary shocks based on rigorous welfare analysis. Devereux and Engel (2003) find that the fixed (floating) exchange rate regime is desirable under local (producer) currency pricing for a small economy in the presence of country-specific real shocks. Duarte and Obstfeld (2008), however, find that the results depend on the prediction that international consumption levels will remain perfectly synchronized under flexible prices. More general modifications of the model that produce nonsynchronous consumption movements make flexible exchange rates optimal.

Gali and Monacelli (2005) analyze the welfare effects of a (1\%) domestic technology shock in a small open economy using a second-order approximation method. They find that a fixed exchange rate results in a welfare loss of some $0.03 \%$ of initial consumption relative to the optimal monetary policy rule. Benigno and Benigno (2006) show that the floating (fixed) exchange rate regime is desirable in cases of productivity (mark-up) shocks. The optimal exchange rate regime depends therefore on the type of disturbance. This literature, however, has not addressed the question of whether the fixed exchange rate is optimal for the foreign country in cases of domestic monetary 
shocks. One of the main findings of this paper, therefore, is that it is also optimal for the dollar bloc to fix the exchange rate in cases of U.S. monetary expansion.

The existing literature, however, describes various motivations for the exchange rate peg in developing countries. However, Mishkin (1998) argues that costs exceed benefits, such as providing an anchor for monetary policy. These costs include the loss of an independent monetary policy, exposure to the transmission of the anchor country's shocks, the increased likelihood of speculative attacks and weakened accountability in pursuing anti-inflationary policies. The biggest problem is that an exchange rate peg can increase financial instability and heighten the potential for financial crises. Frankel (1998), on the other hand, argues that the optimal exchange rate regime varies depending on the specific circumstances of the country in question and the circumstances of the time period in question.

During the global financial crisis, the effects of aggressive U.S. monetary policy on macroeconomic and financial stability in the dollar bloc have drawn attention. Rajan (2011) and Wolf (2008) argue that U.S. monetary policy leads to an overheating of the dollar bloc and rising inflation. Rajan (2011, 107) argues that these lead to "very real problems". On the other hand, Schnabl (2010) analyses the costs and benefits of the dollar peg for China and East Asia and argues that the dollar peg plays a crucial role in the pursuit of macroeconomic stability. This model supports the view of Rajan (2011) and Wolf (2008) that exposure to U.S. monetary policy may lead to an overheating of the dollar bloc: in the model, the dollar bloc's output increases substantially, in comparison to the flexible exchange rate case (recall Figure 2(b)). However, the dollar peg is optimal, from the welfare point of view, even though the high variance of employment is taken into account.

Figure 2(j) shows that under the dollar peg, expansionary U.S. monetary policy leads to rising inflation in the dollar bloc. This result is consistent with that of Erceg et al. (2011), who find that the response of core inflation in the dollar bloc depends qualitatively on whether the dollar bloc pegs the currency or adheres to the Taylor rule. Thus, Rajan's (2011) and Wolf's (2008) arguments that expansionary U.S. monetary policy may be too aggressive for the dollar bloc, thereby creating inflation, seems justified. The model, however, does not support the view that an overheating of the dollar bloc and inflation would lead to real problems: the boom is followed by a slightly negative output gap in the medium term because short term inflation has reduced the real wage below the steady state value.

Several U.S. economists have criticized China's exchange rate policy during the financial crisis. Ben Bernanke, for instance, argues that China's exchange rate policy is blocking a normal recovery process in the global econ- 
omy, a shift in demand towards the struggling U.S. economy (BBC 2011). The model supports this view, since the dollar peg limits the effectiveness of U.S. monetary policy to stimulate U.S. output and prevents improvement in the U.S. current account. In the current environment, in which the U.S. has a current account deficit and an unemployment problem while many dollar bloc countries enjoy near full employment and have substantial current account surpluses, the dollar peg prevents an advantageous rebalancing in the world economy. Moreover, the results suggest that for the apparently realistic parameter combinations of the cross-country elasticity and the Calvo parameter, the value of the dollar peg for the U.S. is negative. This provides a novel rationale for criticism of China's exchange rate policy.

\section{Conclusions}

In this paper, I analyze the consequences of the dollar peg during expansionary U.S. monetary policy. The dollar peg has important implications both for the U.S. and the dollar bloc. A key finding is that the value of the dollar peg is positive for the dollar bloc, since it prevents the U.S. improving its terms of trade at the expense of the dollar bloc. This provides a rationale for fixing the exchange rate to the dollar. The dollar peg, however, leads to an overheating of the economy and rising inflation in the dollar bloc.

The value of the dollar peg, for a wide range of the parameter combinations of the cross-country substitutability and the price rigidity parameter, is negative for the U.S. This provides a rationale for the U.S. to criticize the dollar bloc's (China's) exchange rate policy. In addition, the model support the view that the dollar peg blocs an advantageous rebalancing of the world economy, a shift in demand towards the U.S., which suffers from a current account deficit and unemployment, and away from the dollar bloc countries, which enjoy near full employment and have current account surpluses. This provides an additional rationale for the U.S. to criticize the dollar bloc's exchange rate policy. The model therefore seems to explain quite well the behavior of China and the U.S.: China returned to a tight dollar peg during the U.S. financial crisis, when the Fed cut interest rates aggressively and China's exchange rate policy has been a target of criticism in the U.S. 


\section{References}

[1] Abed, G., S. Nuri Erbas, and B. Guerami, 2003, "The GCC Monetary Union: Some Considerations for the Exchange Rate Regime," IMF Working Paper No. 03/66 (Washington: International Monetary Fund).

[2] Backus D. K., Kehoe P. J. and Kydland F. E, 1992, "International Real Business Cycles," Journal of Political Economy, Vol. 100, 745-775.

[3] BBC 2011, "Ben Bernanke Says US Economy 'Close to Faltering'," available at http://www.bbc.co.uk/news/business-15173683 (retrieved on May 16, 2012)

[4] Benigno, G. and Benigno, P, 2006, "Designing Targeting Rules for International Monetary Policy Cooperation," Journal of Monetary Economics, Vol. 53, 473-506.

[5] Bergin, P. R, 2006, "How Well Can the New Open Economy Macroeconomics Explain the Exchange Rate and Current Account?" Journal of International Money and Finance, Vol. 25, 675-701.

[6] Betts, C. and Devereux, M, 2000, "Exchange Rate Dynamics in a Model of Pricing-to-Market," Journal of International Economics, Vol. 50, 215244.

[7] Bils, M. and Klenow, P, 2004, "Some Evidence on the Importance of Sticky Prices," Journal of Political Economy, Vol. 112, 947-985.

[8] Bluedorn, J. C. and Bowdler, C, 2011, "The Open Economy Consequences of U.S. Monetary Policy," Journal of International Money and Finance, Vol. 30, 309-336.

[9] Broda, C. and Weinstein, D. E, 2006, "Globalization and the Gains from Variety," Quarterly Journal of Economics, Vol. 12, 541-585.

[10] Bordo, M. D., Humpage, O. F. and Schwartz, A. J, 2012, "Epilogue: Foreign Exchange Market Operations in the Twentieth Century," NBER Working Paper No. 17984 (Cambridge, Massachusetts, National Bureau of Economic Research).

[11] Calvo, G, 1983, "Staggered Prices in a Utility Maximizing Framework," Journal of Monetary Economics, Vol. 12, 383-398. 
[12] Cheung, Y-W., Dickson T. and Yiu, M. S, 2007, "Does the Chinese Interest Rate Follow the US Interest Rate?" International Journal of Finance and Economics, Vol. 93, 52-67.

[13] Clarida, R., Galí, J. and Gertler, M, 2000, "Monetary Policy Rules and Macroeconomic Stability: Evidence and Some Theory," Quarterly Journal of Economics, Vol. 115, 147-180.

[14] Corsetti, G. Dedola, L. and Leducl L, 2008, "International Risk Sharing and the Transmission of Productivity Shocks," Review of Economic Studies, Vol. 75, 443-473.

[15] Devereux, M. B. and Engel, C, 2003, "Monetary Policy in the Open Economy Revised: Price Setting and Exchange Rate Flexibility," Review of Economic Studies, Vol. 70, 765-784.

[16] Duarte, M. and Obstfeld, M, 2008, "Monetary Policy in the Open Economy Revisited: The Case for Exchange-Rate Flexibility Restored," Journal of International Money and Finance, Vol. 27, 949-957.

[17] Erceg, C., Guerrieri L. and Kamin L.B, 2011, "Did Easy Money in the Dollar Bloc Fuel the Global Commodity Boom?" International Journal of Central Banking, Vol 7, 131-160.

[18] Feenstra, R., Obstfeld, M. and Russ, K, 2011, "In Search of the Armington Elasticity," (unpublished; University of California, Davis).

[19] Feldstein, M, 1992. The Case Against the EMU. The Economist, June 13.

[20] Frankel, J, 1999, "No Single Currency Regime is Right for All Countries or at All Time," Essays in International Finance (Princeton, Princeton University).

[21] Frankel, J, 2010. China-US Currency Issues. Presentation. Ash Center, June 8, 2010. Available at http://www.hks.harvard.edu/fs/jfrankel/ChinaUSCurrenciesCLDJune2010.ppt (retrieved on June 10th, 2012).

[22] Friedman, M, 1953, "The Case for Flexible Exchange Rates," in Essays in Positive Economics, (Chicago, University of Chicago Press).

[23] Gali, J. and Monacelli, T, 2005, "Monetary Policy and Exchange Rate Volatility in a Small Open Economy," Review of Economic Studies, Vol. $72,707-734$. 
[24] Glick, R. and Hutchison, M, 2009, "Navigating the Trilemma: Capital Flows and Monetary Policy in China," Journal of Asian Economics, Vol. 20, 205-224.

[25] Gopinath, G. and Rigobon, R, 2008, "Sticky Borders," Quarterly Journal of Economics, Vol. 123, 531-575.

[26] Goldberg, L. S. and Tille, C, 2008, "Vehicle Currency Use in International Trade," Journal of International Economics, Vol. 76, 177-192.

[27] Hooper P., Johnson, K. and Marquez, J, 2000, "Trade Elasticities for the G-7 Countries," Princeton Studies in International Economics (Princeton, Princeton University).

[28] Klein, P, 2000, "Using the Generalized Schur Form to Solve a Multivariate Linear Rational Expectations Model," Journal of Economic Dynamics and Control 24, 1405-1423.

[29] Krugman, P, 2010, Taking On China. New York Times, March 15th.

[30] Koivu, T, 2009, "Has the Chinese Economy Become More Sensitive to Interest Rates? Studying Credit Demand in China," China Economic Review, Vol. 20, 455-470.

[31] Lane, P, 2011, "External Imbalances and Macroeconomic Policy in New Zealand," IIIS Discussion Paper No. 376 (Dublin, University of Dublin).

[32] Ma, G. and McCauley, R. N., 2008, "Do China's Capital Controls Still Bind? Implications for Monetary Autonomy and Capital Liberalization," in ed. by. Eichengreen, B., Chul Park, Y. and Wyplosz, C. China, Asia, and the New World Economy, (Oxford, Oxford University Press).

[33] McCallum, B, 2001, "Software for RE Analysis," computer software available at http://wpweb2.tepper.cmu.edu/faculty/mccallum/research.html.

[34] Mishkin, F. S, 1998, "The Dangers of Exchange-Rate Pegging in Emerging-Market Countries," International Finance, Vol. 1, 81-101.

[35] Obstfeld, M. and Rogoff, K, 1995, "Exchange Rate Dynamics Redux," Journal of Political Economy, Vol. 103, 624-660.

[36] Obstfeld, M. and Rogoff, K, 2002, "Global Implications of Self-Oriented National Monetary Rules," Quarterly Journal of Economics, Vol. 117, 503-535. 
[37] Prasad, E.S, 2008, "Monetary Policy Independence, the Currency Regime, and the Capital Account in China," in ed by. Goldstein, M. and Lardy, M. Debating China's Exchange Rate Policy (Washington, DC, Peterson Institute for International Economics)

[38] Rajan, R, 2011, "Currencies Aren't the Problem: Fix Domestic Policy, Not Exchange Rates," Foreign Affairs, Vol. 90, 104-116.

[39] Rogoff, K, 2008, "The World Cannot Grow Its Way Out of This Slowdown," Financial Times, July 29.

[40] Rotemberg, J. J. and Woodford, M, 1992, "Oligopolistic Pricing and the Effects of Aggregate Demand on Economic Activity," Journal of Political Economy, Vol. 100, 1153-1207.

[41] Schmidt, C, 2006, "International Transmission Effects of Monetary Policy Shocks: Can Asymmetric Price Setting Explain the Stylized Facts?" International Journal of Finance and Economics, Vol. 11, 205-218.

[42] Schmitt-Grohe, S and Uribe, M, 2003, "Closing Small Open Economy Models," Journal of International Economics, Vol. 61, 163-185.

[43] Schmitt-Grohe, S and Uribe, M, 2007, "Optimal Simple and Implementable Monetary and Fiscal Rules," Journal of Monetary Economics, Vol. 54, 1702-1725.

[44] Schnabl, G, 2010, "The Role of the Chinese Dollar Peg for Macroeconomic Stability in China and the World Economy," University of Jena, Working Papers on Global Financial Markets No. 13 (Jena, University of Jena).

[45] Stiglitz, J, 2008, "Responding to the Crisis," Presentation, Financial Regulation by the Initiative for Policy Dialogue and Brooks World Poverty Institute, Manchester, July, 2008.

[46] Stiglitz, J, 2010, "Why Easier Money Won't Work," Wall Street Journal, October 23, 2010.

[47] Taylor, J. B, 1993, "Discretion versus Policy Rules in Practice," Carnegie-Rochester Conference Series on Public Policy, Vol. 39, 195214.

[48] Tervala, J, 2012, "International Welfare Effects of Monetary Policy," Journal of International Money and Finance, Vol. 31, 356-376. 
[49] Tille, C, 2001, "The Role of Consumption Substitutability in the International Transmission of Monetary Shocks," Journal of International Economics, Vol. 53, 421-444.

[50] The Economist, 2010, "China Policy Yuanimpressed," July 1.

[51] The Economist, 2011, "Poor Dollar Standard: Has the Downgrade Shaken Loyalty to the Greenback?" August 13.

[52] Wolf, M, 2008, "How Imbalances Led to Credit Crunch and Inflation," Financial Times, June 17.

[53] Zhang, W. 2009, "China's monetary policy: Quantity versus Price Rules," Journal of Macroeconomics, Vol. 31, 473-484. 
Figure 1: Dynamic effects of a U.S. monetary shock under flexible exchange rates
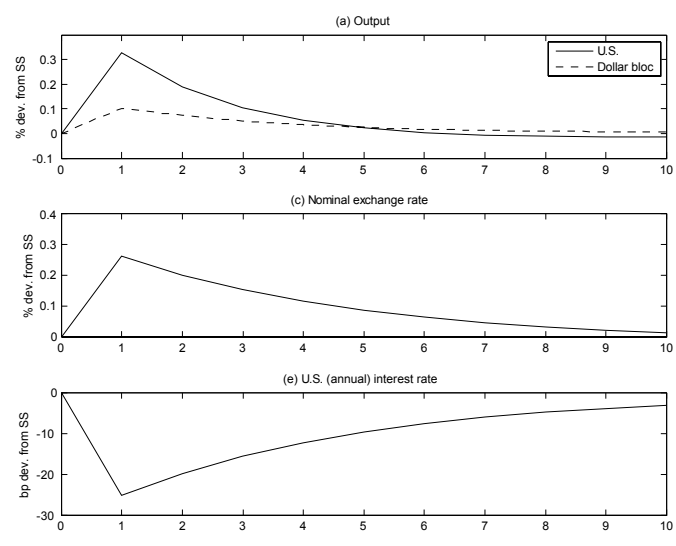

(g) Bond holdings of U.S. households

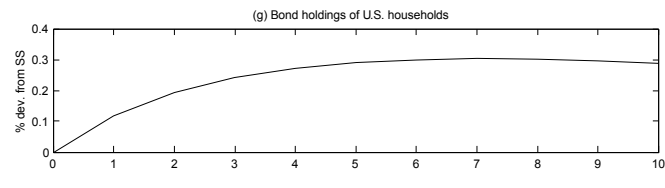

(i) Output, $\rho=1$

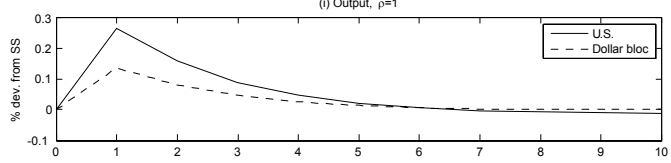

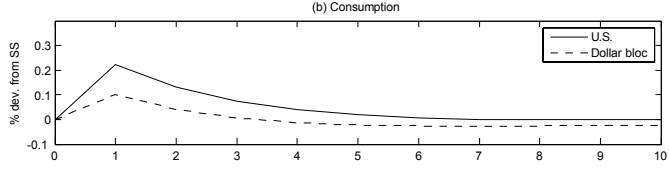

(d) U.S. terms of trade
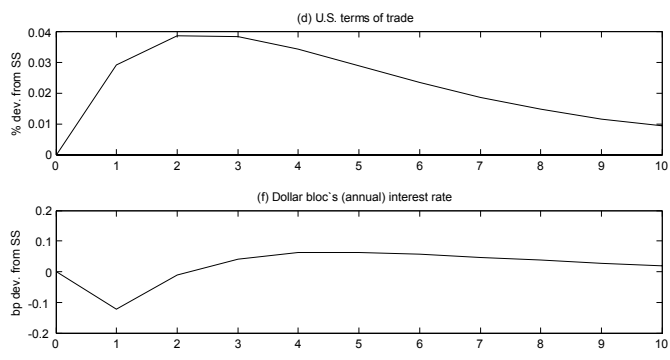

(h) Infation (annual)
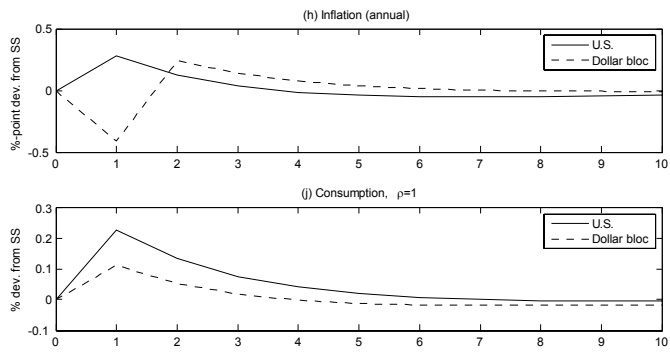
Figure 2: Dynamic effects of a U.S. monetary shock under the dollar peg
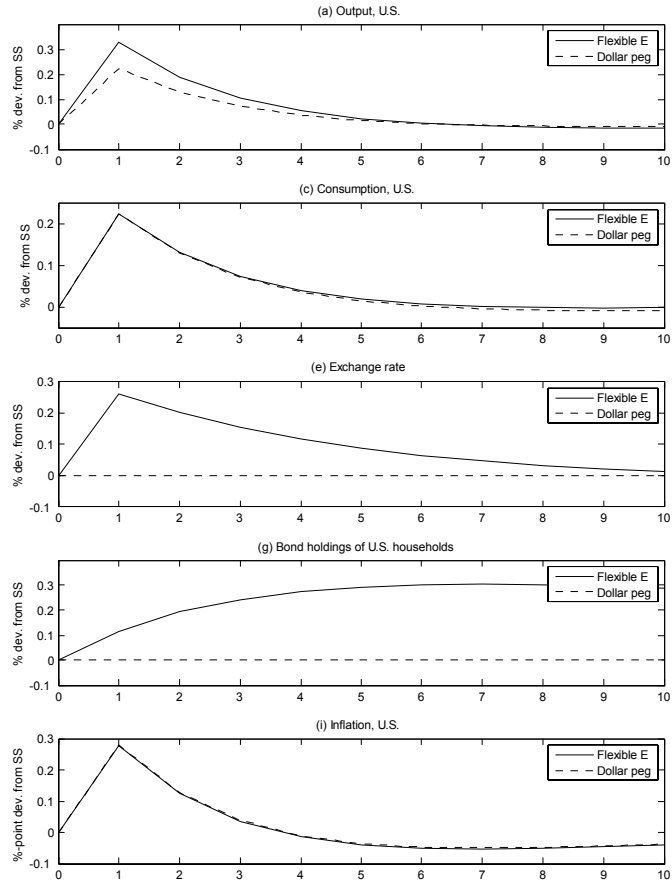
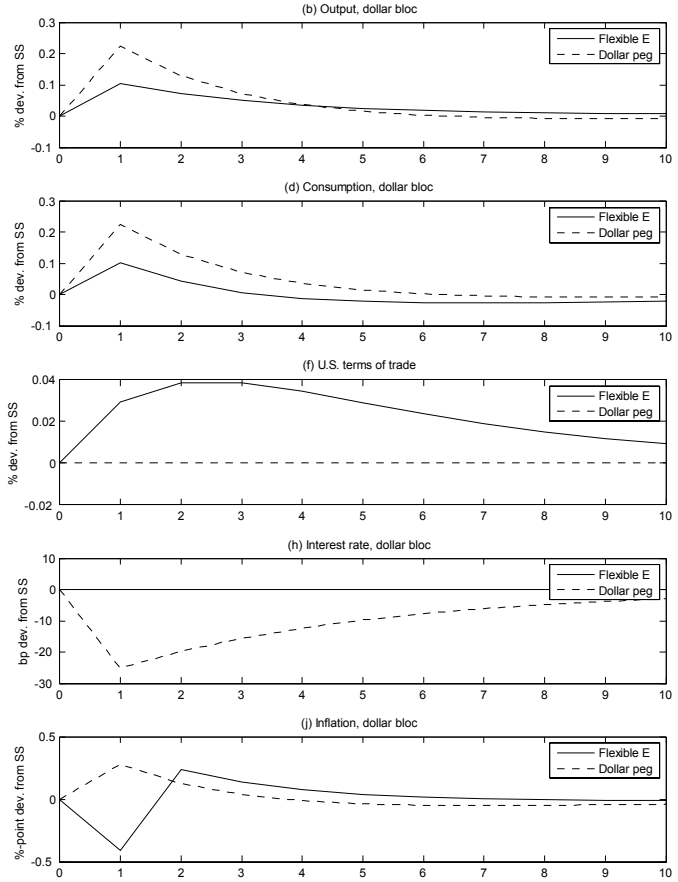